\title{
Transformation and Depuration of Paralytic Shellfish Toxins in the Geoduck Clam Panopea globosa From the Northern Gulf of California
}

\section{OPEN ACCESS}

Edited by:

Marius Nils Müller,

Universidade Federal

de Pernambuco, Brazil

Reviewed by:

Paulo João Vieira Vale, Instituto Português do Mar e da

Atmosfera (IPMA), Portugal

Luiza Dy Fonseca Costa, Fundação Universidade Federal do

Rio Grande, Brazil

*Correspondence:

Ernesto García-Mendoza ergarcia@cicese.mx

Jennifer Medina-Elizalde jennifer.medina.elizalde@gmail.com

Specialty section:

This article was submitted to

Marine Biogeochemistry,

a section of the journal

Frontiers in Marine Science

Received: 02 July 2018

Accepted: 29 August 2018 Published: 24 September 2018

Citation:

Medina-Elizalde J, García-Mendoza E,

Turner $A D$, Sánchez-Bravo YA and Murillo-Martínez R (2018) Transformation and Depuration of Paralytic Shellish Toxins in the Geoduck Clam Panopea globosa From the Northern Gulf of California. Front. Mar. Sci. 5:335.

doi: 10.3389/fmars.2018.00335

\begin{abstract}
Jennifer Medina-Elizalde ${ }^{*}$, Ernesto García-Mendoza ${ }^{2 *}$, Andrew D. Turner ${ }^{3}$, Yaireb Alejandra Sánchez-Bravo ${ }^{2}$ and Ramón Murillo-Martínez ${ }^{2}$
\end{abstract}

\begin{abstract}
${ }^{1}$ Departamento de Biotecnología Marina, Centro de Investigación Científica y de Educación Superior de Ensenada, Ensenada, Mexico, ${ }^{2}$ Departamento de Oceanografía Biológica, Centro de Investigación Científica y de Educación Superior de Ensenada, Ensenada, Mexico, ${ }^{3}$ Centre for Environment, Fisheries and Aquaculture Science (Cefas), Weymouth, United Kingdom
\end{abstract}

In January 2015, a harmful algae bloom (HAB) of the dinoflagellate Gymnodinium catenatum occurred in the Northern Gulf of California (NGC). This species produces paralytic shellfish toxins (PSTs), a group of potent neurotoxins. The harvesting and commercialization of geoduck Panopea globosa are important economic activities in this region and were prohibited for several months due to the accumulation of PSTs in clam tissues. We analyzed PSTs concentrations in P. globosa collected on a weekly basis during 2015 near San Felipe, Baja California. The aim of the study was to evaluate the transformation and depuration characteristics of PSTs in different geoduck tissues. The PST content was evaluated in the visceral mass and in the siphon by high-performance liquid chromatography with post-column oxidation (HPLCPCOX). Additionally, 10 selected samples were analyzed by hydrophilic interaction chromatography coupled to tandem mass spectrometry (HILIC-MS/MS). Toxicity in all siphon samples was lower than the regulatory limit (RL) for PSTs of $800 \mu \mathrm{g}$ STX eq $\mathrm{kg}^{-1}$. In contrast, the maximum toxicity of $16,740 \mu \mathrm{g}$ STX eq $\mathrm{kg}^{-1}$ detected in the visceral mass exceeded 21 times the $R \mathrm{~L}$ and it took 210 days to reach values below $800 \mu \mathrm{g}$ STX eq $\mathrm{kg}^{-1}$. Therefore, $P$. globosa can be considered a slow detoxifier bivalve with a depuration rate of $4.3 \%$ day $^{-1}$ (calculated by an exponential decay model; $R^{2}=0.80$ ). The $\mathrm{N}$-sulfocarbamoyl toxins $\mathrm{C} 1$ and 2 were the most abundant analogs in the siphon and viscera samples collected close to the HAB occurrence. The concentration of these analogs decreased and GTX5 and more toxic analogs such as dcGTX2 and dcSTX were detected. M-type analogs were detected by HILIC-MS/MS and represented up to $75 \%$ of total PSTs in some samples. M-type analogs contributed to $48 \%$ of toxicity estimated in the sample. We report for the first time the depuration rate, PSTs profile, and its change over time in P. globlosa. This information is essential to characterize the metabolism of toxins in this economically important bivalve but also to develop management plans for fisheries if the organism is going to be recurrently exposed to PSTs producing blooms, as seems the case for the NGC. 


\section{INTRODUCTION}

Paralytic shellfish toxins (PSTs) are a group of at least 50 water-soluble neurotoxic alkaloids analogs to saxitoxin (Wiese et al., 2010). Dinoflagellates of the genera Gymnodinium, Alexandrium, and Pyrodinium are the primary producers of PSTs in marine environments (Jaime et al., 2007). PSTs attach reversibly to the voltage-dependent sodium channel and block the pores of the channels. This prevents the transmission of the nerve impulses resulting in neuromuscular paralysis (Cestèle and Catterall, 2000; Bricelj et al., 2005). PSTs vary in their potency or biological activity: the carbamate (saxitoxin STX, neosaxitoxin NEO, and gonyautoxins GTX1-4) are the most potent toxins since they have a higher affinity to sodium channels. $\mathrm{N}$-sulfocarbamoyl toxins (B1 and 2 and $\mathrm{C} 1-4$ ) are the least potent ones, while decarbamoyl toxins (dcGTX1-4, dcSTX, and dcNEO) exhibit intermediate specific toxicities (Bricelj and Shumway, 1998). Figure 1 shows the structures of the primary toxin analogs and are grouped according to the molecular substitutions.

Bivalves, crustaceans, some gastropods, and planktivorous fishes that feed on PSTs producing organisms can accumulate these toxins in their tissues and incorporate them into the food chain. Consumption of contaminated shellfish with PSTs, mainly bivalves, can lead to paralytic shellfish poisoning (PSP) in humans. This syndrome can, at sufficient high toxin concentrations, cause death from cardio respiratory arrest (Botana, 2000). In Mexico, PSP is the most important toxic syndrome related to harmful algae blooms (HABs) of marine species and the only one associated with human fatalities (Lewitus et al., 2012). In Mexico, PSP has affected at least 460 individuals with 32 recognized fatalities (Band-Schmidt et al., 2010; Bustillos-Guzmán et al., 2016; Santiago-Morales, 2016). The first recognized PSP outbreak occurred in 1979 in the coast of Sonora to Jalisco (Figure 2) and was associated with a bloom of Gymnodinium catenatum (Mee et al., 1986). The intoxication of 19 people occurred, including three deaths, as well as an extensive fish die-off (De la Garza, 1983; Mee et al., 1986). Other outbreaks have been documented along the Mexican Pacific coast (Bustillos-Guzmán et al., 2016). The bivalves responsible for the intoxications were not identified in the majority of the outbreaks. However, PSTs have been detected in shellfish in most of these events. In the 1979 outbreak, the rocky oyster Crassostrea iridiscens accumulated 10,700-17,200 $\mu \mathrm{g}$ STX eq kg-1 and the clam Donax sp. accumulated 76,400 $\mu \mathrm{g}$ STX eq $\mathrm{kg}^{-1}$ (Mee et al., 1986). In November 1989, three people died and 99 others became intoxicated in the Gulf of Tehuantepec region (Oaxaca coast, Mexican tropical Pacific, Figure 2) and the accumulation of $8,110 \mu \mathrm{g}$ STX eq $\mathrm{kg}^{-1}$ in oyster was documented (SaldateCastañeda et al., 1991). Also along the Oaxaca coast, three people died and 17 were intoxicated between August 2001 and February 2002. Associated with this outbreak, up to $14,560 \mu \mathrm{g} \mathrm{STX} \mathrm{eq} \mathrm{kg}^{-1}$ were detected in mussels (Ramírez-Camarena et al., 2004; BandSchmidt et al., 2010; Santiago-Morales, 2016).

In general, the species responsible for the accumulation of the PSTs during the outbreaks are G. catenatum in the northern coasts of the Mexican Pacific Ocean and Pyrodinium bahamense var. compressum in the south (Lewitus et al., 2012; Bustillos-Guzmán et al., 2016; Santiago-Morales, 2016). Most HABs of these species occur between February and May when the water temperature is between $17-25^{\circ} \mathrm{C}$ (Manrique and Molina, 1997; Gárate-Lizárraga et al., 2004, 2006; Lewitus et al., 2012). In January 2015, an intense and extensive HAB of G. catenatum occurred in the north of the Gulf of California (GC; Figure 2). This HAB affected the economy, the ecology, and public health of the region. Most notably, the $\mathrm{HAB}$ was associated with seabirds and marine mammal die-offs (Garcia-Mendoza et al., in preparation), also resulting in the intoxication of at least five people at Los Angeles Bay after the ingestion of wild bivalves (Comisión Federal para la Protección contra Riesgos Sanitarios, 2015). As a direct consequence of this bloom, the extraction and commercialization of some shellfish species was prohibited

\begin{tabular}{|c|c|c|c|c|c|c|c|c|c|}
\hline \multirow{11}{*}{$\mathrm{R}_{4}$} & R1 & R2 & R3 & $\begin{array}{l}\text { Carbamate } \\
\text { toxins }\end{array}$ & $\begin{array}{l}\text { N-Sulfocarbamoyl } \\
\text { toxins }\end{array}$ & $\begin{array}{c}\text { Decarbamoyl } \\
\text { toxins }\end{array}$ & \multicolumn{3}{|c|}{$\begin{array}{l}\text { Others analogues } \\
\text { M toxins }\end{array}$} \\
\hline & $\mathrm{H}$ & $\mathrm{H}$ & $\mathrm{H}$ & STX & B1 (GTX5) & dcSTX & & & \\
\hline & $\mathrm{OH}$ & $\mathrm{H}$ & $\mathrm{H}$ & NEO & B2 (GTX6) & dcNEO & & & \\
\hline & $\mathrm{OH}$ & $\mathrm{H}$ & $\mathrm{OSO}_{3}^{-}$ & GTX1 & $\mathrm{C} 3$ & dcGTX1 & & & \\
\hline & $\mathrm{H}$ & $\mathrm{H}$ & $\mathrm{OSO}_{3}^{-}$ & GTX2 & $\mathrm{C} 1$ & dcGTX2 & & & \\
\hline & $\mathrm{H}$ & $\mathrm{OSO}_{3}^{-}$ & $\mathrm{H}$ & GTX3 & $\mathrm{C} 2$ & dcGTX3 & & & \\
\hline & $\mathrm{OH}$ & $\mathrm{OSO}_{3}^{-}$ & $\mathrm{H}$ & GTX4 & $\mathrm{C} 4$ & dcGTX4 & & & \\
\hline & $\mathrm{H}$ & $\mathrm{OH}$ & $\mathrm{H}$ & & & & M1 & M2 & \\
\hline & $\mathrm{H}$ & $\mathrm{OH}$ & $\mathrm{OH}$ & & & & M3 & M4 & \\
\hline & & $\begin{array}{l}\text { Iot structu } \\
\text { characteri }\end{array}$ & & & & & & & M5 \\
\hline & & & & $\begin{array}{c}\mathrm{R} 4 \\
\mathrm{OCONH}_{2}\end{array}$ & $\begin{array}{c}\mathbf{R} 4 \\
\mathrm{OCONHCH}_{3}\end{array}$ & $\begin{array}{l}\mathrm{R} 4 \\
\mathrm{OH}\end{array}$ & $\begin{array}{c}\mathrm{R} 4 \\
\mathrm{OCONH}_{2}\end{array}$ & $\begin{array}{c}\mathrm{R} 4 \\
\mathrm{OCONHCH}_{3}\end{array}$ & \\
\hline
\end{tabular}

FIGURE 1 | Structure of the paralytic shellfish primary toxin analogs, grouped according to the molecular substitutions. 


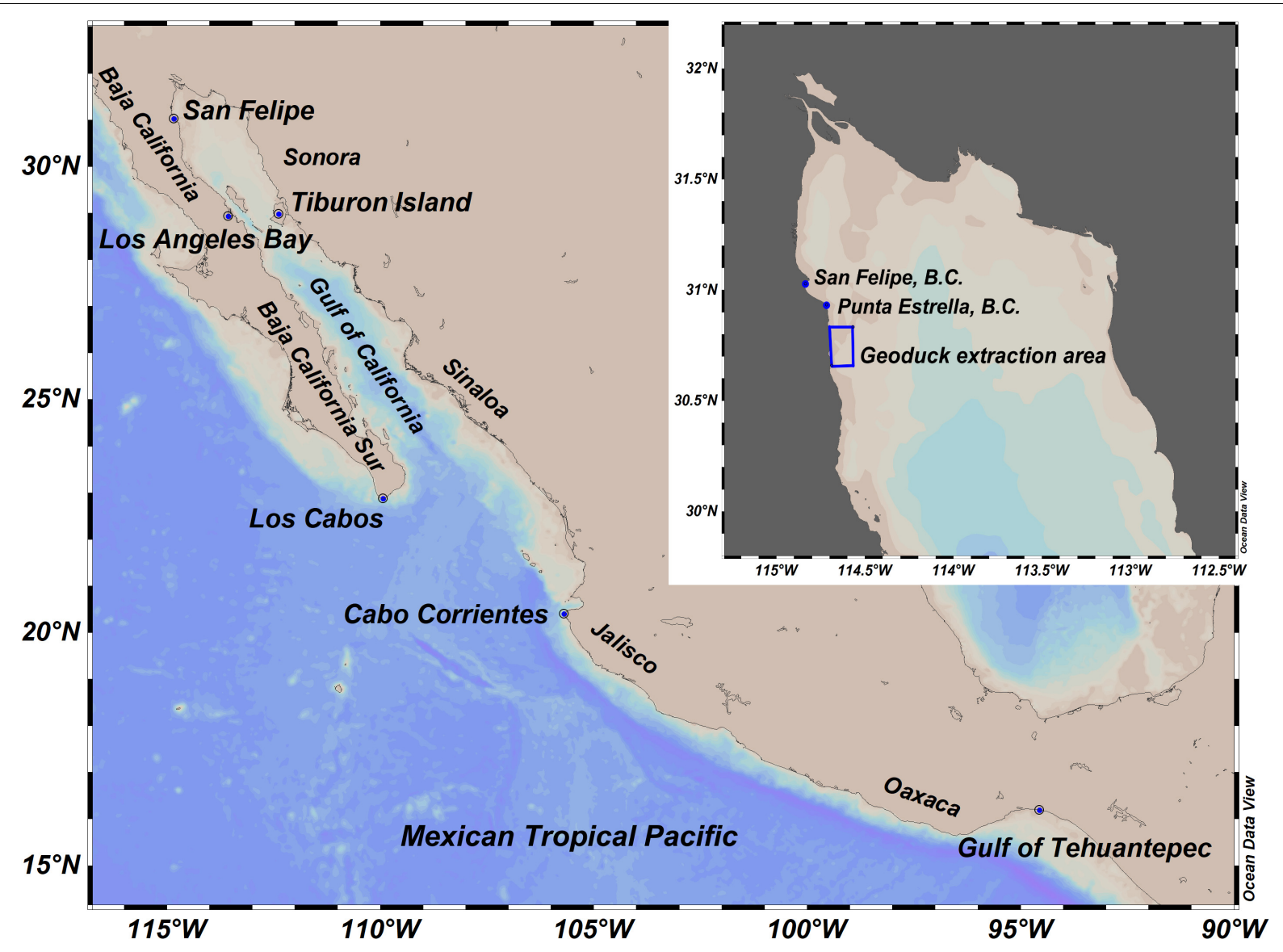

FIGURE 2 | Gulf of California and Mexican Tropical Pacific where outbreaks of paralytic shellfish toxins have occurred. The northern part of the Gulf of California and the location of Atenea en el Mar company federal approved area for harvesting of Panopea globosa in San Felipe, BC, are presented in the inset of the map.

almost all year. Harvesting of Panopea globosa was particularly affected.

Panopea globosa is an endemic geoduck clam from the northwest coast of Mexico. Its distribution extends from the upper GC to Magdalena Bay on the Pacific side of the Baja California peninsula (Aragón-Noriega et al., 2012). Geoducks clams are large infaunal bivalves, their shells can be larger than $25 \mathrm{~cm}$, the siphon may exceed $1 \mathrm{~m}$ in length and can reach $2 \mathrm{~kg}$ of weight (Goodwin and Pease, 1987). These organisms live buried in the sediment ranging from the intertidal zone to a depth of $110 \mathrm{~m}$ (Bureau et al., 2002). P. globosa is one of the most important economic resources of the GC. San Felipe is the main port of arrival for these bivalves with a mean production of $848 \mathrm{t} \mathrm{year}^{-1}$ from 2005 to 2010 that represent approximately 10 million USD per year (Secretaría de Pesca de Baja California, 2016). The market for Mexican geoducks is the United States and Asian countries which demands live adult organisms (Aragón-Noriega et al., 2012). The sanitary ban implemented in 2015 significantly affected the industry in the Northern Gulf of California (NGC). The extraction of the clams was prohibited for 5 consecutive months and after June 2015, closures occurred intermittently for another 5 months due to the detection of PSTs concentrations in visceral mass above the regulatory limit (RL) of $800 \mu \mathrm{g}$ STX eq $\mathrm{kg}^{-1}$ (Comisión Federal para la Protección contra Riesgos Sanitarios, 2015).

Accumulation of PSTs in geoduck species has been only characterized in Panopea generosa (=Panopea abrupta). The intra- and inter-population toxin variability was described in organisms from two localities of the Washington coast (Curtis et al., 2000). PSTs concentrations were highly variable among locations and between the sampling depths of the organisms. Most important, the amount of toxins accumulated in viscera was much higher than in the siphon and its concentration was above the RL for the entire 5 months of the study (Curtis et al., 2000). There was no information about the presence of the phytoplankton organism producing the PSTs. However, the data indicated that $P$. generosa is a slow depurating organism, with PSTs being retained in the tissues for long periods of time. There is no information about the PSTs metabolism in P. globosa. Therefore, the aim of this present study was to describe the transformation and depuration of PSTs in viscera and the siphon of the geoduck P. globosa. This information is important for the characterizations of PSTs metabolic processes in bivalves and it is necessary for the management of this important regional fishery in case of HABs producing PSTs. 


\section{MATERIALS AND METHODS}

\section{Study Area and Sample Collection}

The GC, located in the northwest of Mexico, is a narrow shelf sea of approximately $1,100 \mathrm{~km}$ length and $150 \mathrm{~km}$ width (Gutiérrez et al., 2004). The GC is a productive semienclosed sea that supports several industrial and small-scale fisheries (Cudney-Bueno et al., 2009). The GC is situated between the Baja California Peninsula (West) and the Sonora and Sinaloa coasts (East). The Northern border is limited by the Colorado River base level and the Southern border is delimited by an imaginary line from the tip of the Baja California Peninsula to Cabo Corrientes, Jalisco, Mexico (Espinosa-Carreón and ValdézOlguín, 2007). The Northern Gulf goes from Colorado River to the south of Tiburon Island (Figure 2).

There are approximately 20 Panopea harvesting areas in the NGC. The laboratory FICOTOX of Centro de Investigación Científica y de Educación Superior de Ensenada, Baja California (CICESE) has been monitoring the phytoplankton community intermittently since 2011 in surface water samples collected from a harvesting area located south from San Felipe, Baja California, Mexico $\left(30^{\circ} 39^{\prime} 30^{\prime \prime}-30^{\circ} 50^{\prime} 00^{\prime \prime} \mathrm{N}\right.$ and $114^{\circ} 34^{\prime} 00^{\prime \prime}-114^{\circ} 41^{\prime} 15^{\prime \prime} \mathrm{W}$; Figure 2). This area is a federal concession to the company Atenea en el Mar for geoduck extraction. After the detection of the bloom, water samples were collected every week from January to June of 2015. Also, geoduck clams were collected every week in this area after the detection of the bloom.

The phytoplankton community was evaluated in water samples collected at the surface and from $10 \mathrm{~m}$ depth vertical net hauls; $250 \mathrm{~mL}$ of water were placed in dark plastic bottles (Nalgene type) and fixed with 1-2 mL of a concentrated lugolacetate solution. This solution is recommended for evaluation of the phytoplankton community with the Utermöhl technique (Sournia, 1978). Lugol-acetate increases the settling velocity of microalgae, and can be used for the majority of phytoplankton species without damaging the cells. Also, has low toxicity to humans compared with other fixatives (Andersen and Throndsen, 2004). The Utermöhl technique (Sournia, 1978) was used to identify and to evaluate phytoplankton cell abundance; $10-25 \mathrm{~mL}$ of the sample were sedimented for at least $24 \mathrm{~h}$ and the complete surface of the sedimentation chamber was analyzed with a LEICA DMI3000B (Leica Microsystems, Germany) inverted microscope. The abundance of $G$. catenatum (in cells $\mathrm{L}^{-1}$ ) was calculated according to the sedimented volume. A minimum of 500 cells were counted to estimate the relative abundance of $G$. catenatum to total phytoplankton cells (in \%) present in samples collected from net hauls.

Geoduck clams collected by scuba diving at 12-20 $\mathrm{m}$ depth were maintained in cooler boxes and kept at $12-16^{\circ} \mathrm{C}$ until delivery to the laboratory. Samples were transported to the laboratory FICOTOX in less than $24 \mathrm{~h}$ after the collection. Associated with internal paperwork problems of the company some organisms could not be delivered to the laboratory after field sampling. Organisms collected on June 7 and 29, July 2 and 25, and August 7 and 8 were kept alive in the company tanks without food at $18^{\circ} \mathrm{C}$ before delivering the samples to the laboratory. These samples arrived at the laboratory no more than 8 days after collection from the field.

Once in the laboratory, organisms were dissected. The toxin content was evaluated both in the visceral mass that contains all the geoduck organs and in the siphon, the muscular part of the organism. To obtain a representative sample and according to recommendations of the national sanitary regulation for PSTs monitoring in geoduck (Secretaría de Salud, 2016), each sample consisted of three individuals. The tissues of the three dissected organisms were pooled together, homogenized in a blender and kept frozen at $-20^{\circ} \mathrm{C}$ until its analysis by highperformance liquid chromatography with post-column oxidation (HPLC-PCOX) according to Van de Riet et al. (2011). To extract the toxins, $5 \mathrm{~g}$ of each tissue homogenate (consisting of three siphons or three visceral masses) were mixed with $5 \mathrm{~mL}$ of $0.1 \mathrm{M}$ $\mathrm{HCl}$ and boiled for $5 \mathrm{~min}$. After cooling to room temperature, samples were centrifuged at 3,000 $\mathrm{g}$ for $10 \mathrm{~min}$ and an aliquot of $500 \mu \mathrm{L}$ of the supernatant was recovered and deproteinized with $35 \mu \mathrm{L}$ of trichloroacetic acid (TCA) 30\% solution. The $\mathrm{pH}$ was adjusted to 3 before and after the boiling step with $5 \mathrm{M} \mathrm{NaOH}$ or $5 \mathrm{M} \mathrm{HCl}$. The $\mathrm{pH}$ was also adjusted after the addition of the TCA with $25 \mu \mathrm{L}$ of $0.1 \mathrm{M} \mathrm{NaOH}$. The aliquot was subsequently filtered through a $45 \mu \mathrm{m}$ pore size nylon membrane filter before injection onto the HPLC-PCOX system.

\section{Quantification of PSTs by HPLC-PCOX}

HPLC-PCOX was conducted as described by Van de Riet et al. (2011). The analysis was performed using an Agilent Technologies 1100 model HPLC (Agilent, United States) calibrated with eight certified reference standards obtained from the Institute of Biotoxin Metrology, National Research Council Canada (NRC, Halifax, Nova Scotia, Canada). For C toxins (C1 and 2) $5 \mu \mathrm{L}$ of each sample was injected onto an Agilent Zorbax SB-C8 $(250 \mathrm{~mm} \times 4.6 \mathrm{~mm}, 5 \mu \mathrm{m})$ HPLC column. For GTX toxins (GTX1 and 4, GTX2 and 3, dcGTX2 and 3, GTX5) and STX toxins (NeoSTX, STX, dcSTX) $10 \mu \mathrm{L}$ of each sample were injected onto an Agilent Zorbax Bonus-RP $(150 \mathrm{~mm} \times 4.6 \mathrm{~mm}, 3.5 \mu \mathrm{m})$ column. After the chromatographic separation, samples were oxidized online in a Vector PCX derivatization instrument (Pickering Labs Inc., United States) and detected by fluorescence. Excitation was at $330 \mathrm{~nm}$ and emission detection at $395 \mathrm{~nm}$. When the concentration of PSTs in samples was higher than the calibration curve concentration range, extracts were diluted with a $0.1 \mathrm{M} \mathrm{HCl}(\mathrm{pH} 3)$ solution. The dilution factor was considered in the calculation of PSTs concentration.

Total toxicity of the sample was calculated by the multiplication of the concentration of each toxin, the molecular weight of STX diHCl and the toxicity equivalent factor (TEF) of each analog according to Oshima (1995; Table 1).

\section{Quantification of PSTs by HILIC-MS/MS}

Ten selected samples collected at different dates were also analyzed by hydrophilic interaction liquid chromatography coupled to tandem mass spectrometry (HILIC-MS/MS). After 
the centrifugation step, the sample was lyophilized and sent for analysis to the Centre for Environment, Fisheries, and Aquaculture Science (Cefas). Here, the samples were subjected to semiautomated solid phase (SPE) clean-up using Supelclean ENVI-Carb $250 \mathrm{mg} 3 \mathrm{~mL}^{-1}$ SPE cartridges (Sigma-Aldrich, St. Louis, MO, United States). Sample extracts were eluted and collected through the addition of $2 \mathrm{~mL} \mathrm{20 \%}$ acetonitrile $(\mathrm{MeCN})+0.25 \%$ acetic acid at $3 \mathrm{~mL} \mathrm{~min}^{-1}$. SPE eluents were vortex-mixed prior to dilution of $100 \mu \mathrm{L}$ aliquots in $700 \mu \mathrm{L}$ Verex polypropylene autosampler vials (Phenomenex, Manchester, United Kingdom) with $300 \mu \mathrm{L}$ MeCN.

HILIC-MS/MS was conducted according to Boundy et al. (2015) using a $1.7 \mu \mathrm{m}, 2.1 \mathrm{~mm} \times 150 \mathrm{~mm}$ Waters (Manchester, United Kingdom) Acquity BEH Amide UPLC column in conjunction with a Waters VanGuard BEH Amide guard cartridge; $2 \mu \mathrm{L}$ were injected into a Waters Acquity UPLC I-Class coupled to a Waters Xevo TQ-S tandem quadrupole mass spectrometer (MS/MS). The HILIC-MS/MS method was calibrated with nine STX analogs with certified reference standards obtained from NRC (C1 and 2, dcGTX2 and 3, GTX2 and 3, GTX1 and 4, GTX5, dcSTX, dcNEO, NEO, STX) plus four reference materials (C3 and 4, GTX6, doSTX, and tetrodotoxin TTX) from Cawthron Natural Compounds (CNC, New Zealand) and CIFGA laboratories (Lugo, Spain). Levels of toxins with no reference standards, such as dcGTX1 and 4 and M-toxins, were semiquantified using the response factor of the nearest structural analog with a certified standard and applying a relative response factor (RRF; Boundy et al., 2015; (1.8 for dcGTX1, 1.93 for dcGTX4, and 1 for M toxins; Turner et al., 2015). In the absence of relative toxicity data for M-toxins, TEFs were taken from structurally similar PSTs analogs (Table 1).

\section{Data Analysis}

SigmaPlot 11.0 (Systat Software Inc.) was used to fit an exponential decay function to the change of PSTs in time. Also, the software was used to fit a linear model and an exponential rise to a maximal regression model to the PSTs present in the siphon in relation to the concentration of these toxin in the visceral mass.

TABLE 1 | Toxin equivalent factors (TEFs; Oshima, 1995) applied for quantitation and semiquantitation of PST analogs.

\begin{tabular}{lllllc}
\hline Analog & TEF & Analog & TEF & Analog & TEF \\
\hline C1 & 0.01 & GTX2 & 0.4 & dcNEO & 0.4 \\
C2 & 0.1 & GTX3 & 0.6 & STX & 1 \\
C3 & 0.02 & GTX1 & 0.99 & NEO & 0.9 \\
C4 & 0.1 & GTX4 & 0.7 & M1 & $0.1^{\mathrm{c}}$ \\
dcGTX2 & 0.15 & GTX5 & 0.06 & M2 & 0.3 \\
dcGTX3 & 0.4 & GTX6 & 0.1 & M3 & $0.1^{c}$ \\
dcGTX1 & $0.5^{\mathrm{a}}$ & doSTX & $0.05^{\mathrm{b}}$ & $\mathrm{M} 4$ & $0.3^{\mathrm{d}}$ \\
dcGTX4 & $0.5^{\mathrm{a}}$ & dcSTX & 0.5 & $\mathrm{M} 5$ & $0.1^{\mathrm{c}}$
\end{tabular}

${ }^{a}$ dcGTX1 and dcGTX4 based on assumed toxicity equivalency factors (Sullivan et al., 1983). ${ }^{b}$ doSTX toxicity equivalency factor (Harwood et al., 2014). ${ }^{c}$ Toxicity factors derived from EFSA GTX5 and GTX6. 'Toxicity factors derived from EFSA $110 \mathrm{H}-\mathrm{STX}$

\section{RESULTS}

\section{Gymnodinium catenatum Abundance}

The phytoplankton community has been monitored by the laboratory FICOTOX intermittently from 2011 in surface water samples collected every two weeks or every month in the P. globosa extraction area located south from San Felipe. In general, $G$. catenatum has been present from December to April and surface abundances has been no higher than $10 \times 10^{3}$ cells $\mathrm{L}^{-1}$ before 2015 (data not shown). On January 14, 2015 , the abundance of this dinoflagellate reached $152 \times 10^{3}$ cells $\mathrm{L}^{-1}$ (Figure 3A). From this date, surface and vertical net tow water samples were analyzed on a weekly basis. One week after, the maximum abundance was detected the presence of G. catenatum decreased to $9.3 \times 10^{3}$ cells $\mathrm{L}^{-1}$. Detection of this species at the water surface continued in the following weeks and a second abundance peak was registered on February 24 $\left(18.5 \times 10^{3}\right.$ cells $\left.\mathrm{L}^{-1}\right)$. After this date, this species disappeared and was detected again in April and May at abundances lower than of $3.8 \times 10^{3}$ cells $\mathrm{L}^{-1}$ (Figure $3 \mathbf{A}$ ).

The abundance of $G$. catenatum evaluated in vertical net tow samples clearly showed the presence of the bloom in the area (Figure 3B). The relative abundance of this species (abundance of $G$. catenatum to total phytoplankton cells in the net sample) was $55 \%$ on January 14 and decreased in the following weeks. The relative abundance increased in February and reached a maximum abundance of $87 \%$. G. catenatum was detected in net tow samples until March 10. This species disappeared after this date and was detected again on May 1 with a relative abundance of $62 \%$. G. catenatum appeared in net tow samples on May 12 for the last time with relative abundance of $27 \%$ (Figure 3B).

\section{Toxicity in the Siphon and Visceral Mass of $P$. globosa}

The visceral mass (viscera ball) contains the gut, the digestive gland, gonads, heart, kidney, and gills. Although this part of the clams is rarely consumed, the visceral mass is the target tissue to evaluate the concentration of PSTs in geoduck clams. The muscle (siphon) is the part of the organism that is preferentially consumed. PST concentrations together with their transformation and depuration were evaluated in both tissues. Toxin concentrations were determined in 23 siphon and 40 viscera ball samples collected in 2015. Also, toxin concentrations in nine samples collected in 2017 were considered in the analysis of the relation between the siphon and viscera toxicity (see below).

Paralytic shellfish toxins were present in the siphon, although concentrations were lower than the RL of $800 \mu \mathrm{g} \mathrm{STX} \mathrm{eq} \mathrm{kg} \mathrm{g}^{-1}$ in all samples (Figure 3C). The highest PSTs concentration (429 $\mu \mathrm{g}$ STX eq $\mathrm{kg}^{-1}$ ) was detected on January 27 and decreased from this day. The lowest concentration was detected after five months $\left(60 \mu \mathrm{g}\right.$ STX eq $\mathrm{kg}^{-1}$ ) from the quantification of the maximum PSTs accumulation (Figure 3C). Therefore, after July, no more samples of siphon were processed. An exponential decay model was fitted to the data describing the reduction in toxicity level over time. The determination coefficient $\left(R^{2}\right)$ was 0.82 and the 
A

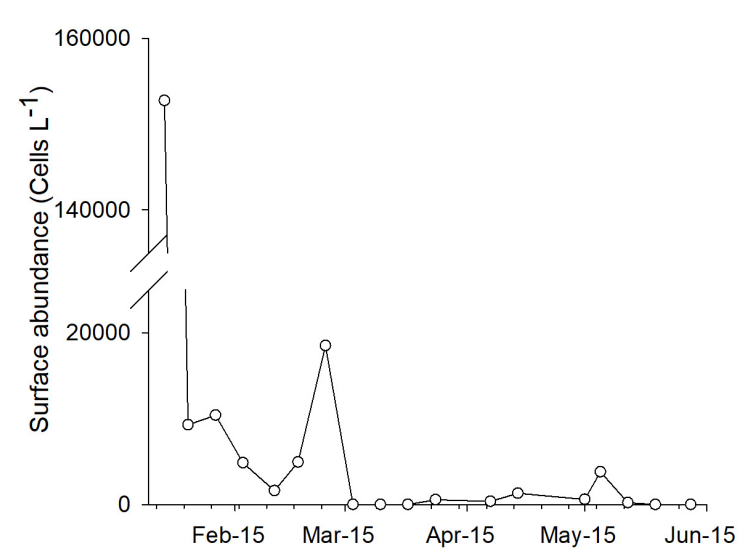

C

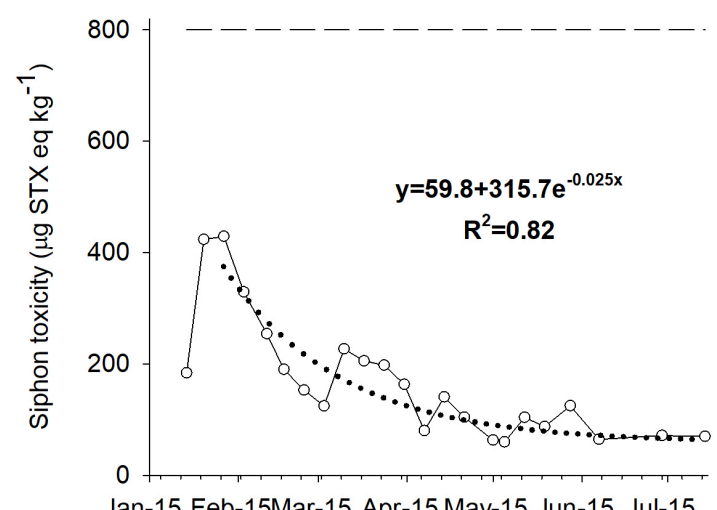

B

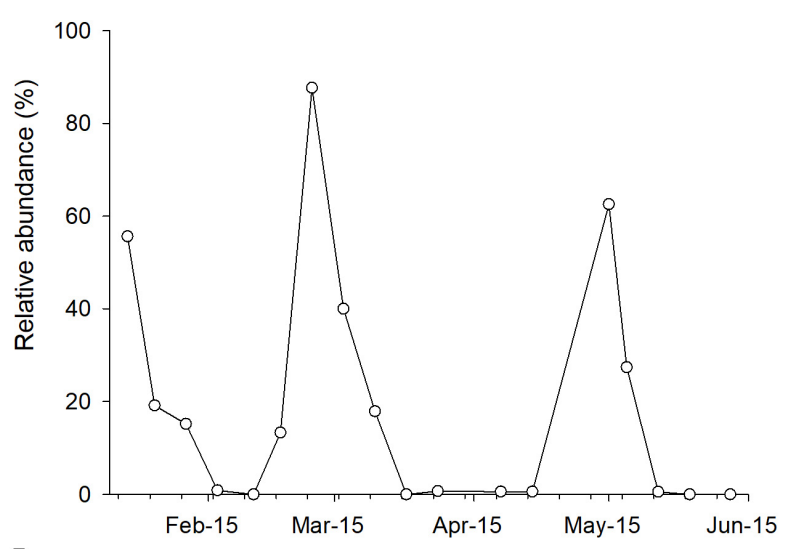

D

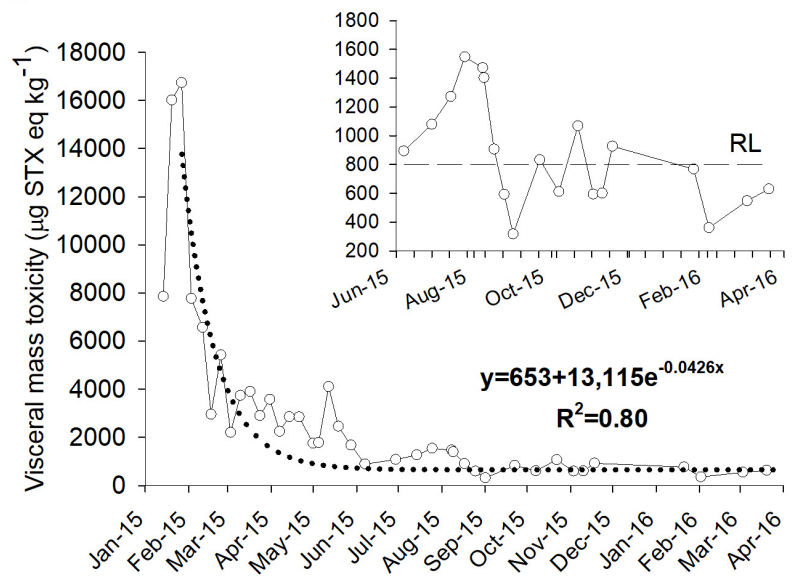

FIGURE 3 | Surface (A) and relative abundance (B) of Gymnodinium catenatum during 2015 in the northern region of the Gulf of California. Toxicity associated with paralytic shellfish toxins in the siphon (C) and visceral mass (D) of geoduck samples collected from January 2015 to April of 2016. Dotted line shows the fitted of exponential decay function to the data and the dashed line is the regulatory limit (RL) of $800 \mu \mathrm{g} \mathrm{STX} \mathrm{eq} \mathrm{kg}^{-1}$.

calculated depurating rate of PSTs in the siphon was $2.5 \%$ of toxin loss per day (Figure 3C).

Panopea globosa accumulated PSTs mainly in the visceral mass. Maximum PSTs concentration within these tissues reached $16,740 \mu \mathrm{g}$ STX eq $\mathrm{kg}^{-1}$ in January. This concentration represented 21 times the RL (Figure 3D). The toxicity was higher than this limit for approximately eight months. A sample with a concentration lower than $800 \mu \mathrm{g}$ STX eq $\mathrm{kg}^{-1}$ was detected on August 25, 210 days after the detection of the maximum concentration. However, the toxicity increased again in the following weeks and fluctuated around the RL during the rest of 2015. The last sample processed for the study was collected in March 2016 and presented a PSTs concentration of $629 \mu \mathrm{g}$ STX eq $\mathrm{kg}^{-1}$.

An exponential decay model was also fitted to the change of PSTs in viscera over time $\left(R^{2}=0.80\right)$. The maximum PSTs concentration detected on January 27 was the first data used in the analysis (Figure 3D). The calculated depuration rate was $4.3 \%$ of toxin loss per day. According to this, the PSTs concentration should have reached the RL 106 days after the maximum concentration was detected.
Paralytic shellfish toxins in the siphon were related to the concentration of these toxins in the visceral mass. This relation is shown in Figure 4. PSTs concentrations detected in viscera and siphon after another HAB that occurred in January 2107 were also considered in this analysis. On January 24 of 2017 , G. catenatum

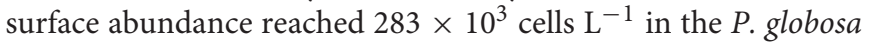
extraction area. The relative abundance of $G$. catenatum in net tow samples was $87 \%$ on this date.

After the $2017 \mathrm{HAB}$, concentrations above $800 \mu \mathrm{g}$ STX eq $\mathrm{kg}^{-1}$ were detected in three siphon samples (Figure 4). An exponential rise to a maximal value function explains $78 \%$ $\left(R^{2}=0.78\right)$ of the variance between PSTs present in the siphon in relation to the presence of these toxin in the viscera. However, a high PSTs concentration detected in the siphon $(1,063 \mu \mathrm{g}$ STX eq $\mathrm{kg}^{-1}$ ) clearly influenced the relation and increased $R^{2}$ when the exponential function is considered. This concentration in the siphon was detected when viscera presented 49,166 $\mu \mathrm{g}$ STX eq $\mathrm{kg}^{-1}$. Regression analysis considering different models (linear, exponential, polynomial) were performed without considering these high concentrations of PSTs (outlier). PSTs in the siphon were linearly related (best fit) to the concentration detected in 


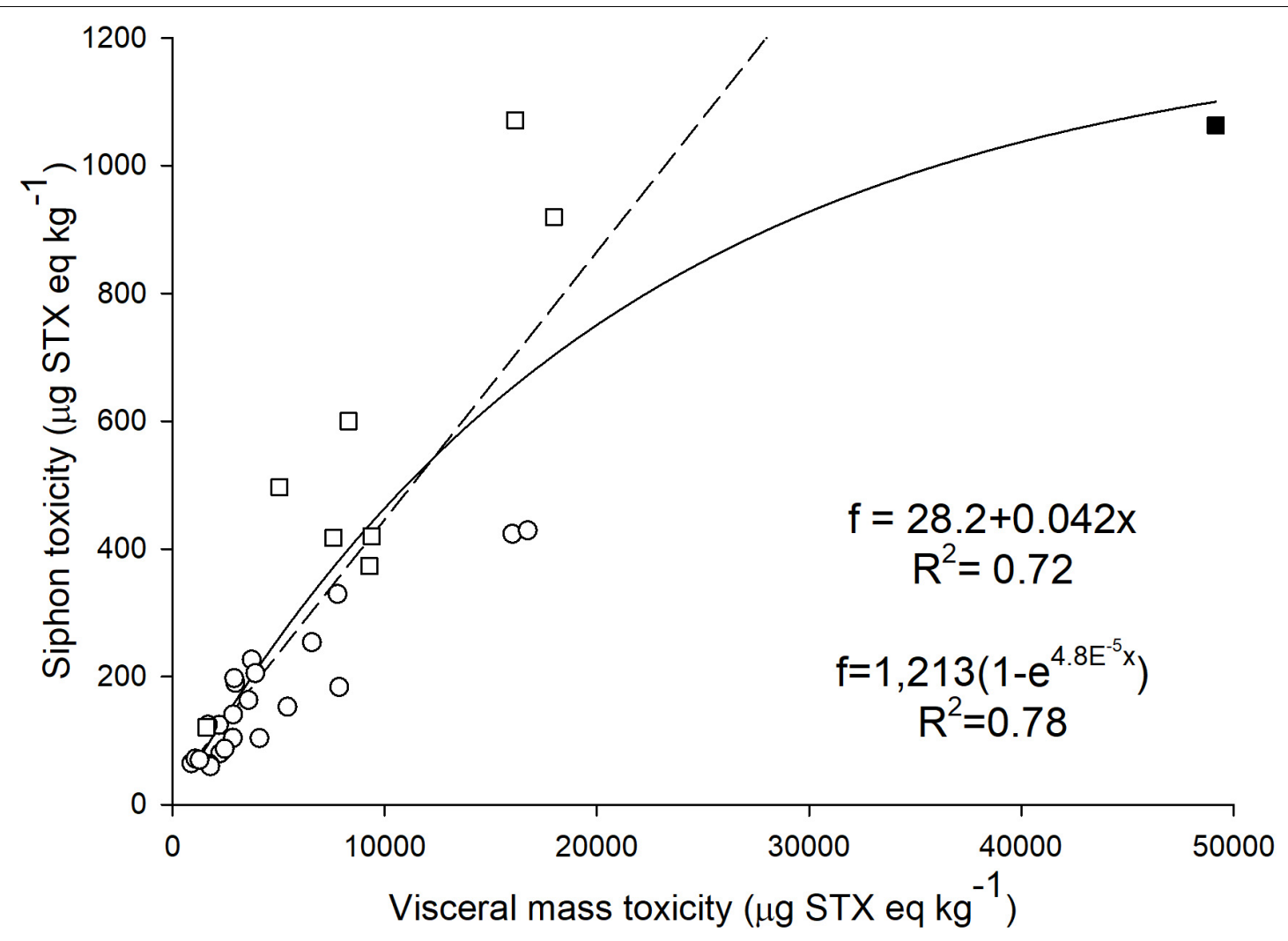

FIGURE 4 | Relation between calculated toxicity of the siphon and visceral mass in geoduck samples collected during 2015 (circles) and 2017 (squares). The filled square shows the highest paralytic shellfish toxin concentration detected in viscera in 2017. This point was omitted (outlier) when a linear regression analysis was applied $\left(R^{2}=0.72\right.$, dashed line; see text). An exponential rise to a maximal function was used for the regression analysis considering all data $\left(R^{2}=0.78\right.$, solid line).

viscera below 20,000 $\mu \mathrm{g}$ STX eq $\mathrm{kg}^{-1}\left(R^{2}=0.72\right.$; Figure 4). According to this model, toxicity in viscera was 23.8 times higher than the one detected in the siphon. Importantly, the toxicity in the siphon will exceed the RL when toxicity in visceral mass reaches $18,424 \mu \mathrm{g}$ STX eq $\mathrm{kg}^{-1}$.

\section{Paralytic Shellfish Toxins in the Siphon and Visceral Mass of $P$. globosa}

To characterize the accumulation and biotransformation process of PSTs, it is essential to evaluate the analogs present in the samples. Therefore, we evaluated the concentrations of 12 PSTs analogs in both the siphon and visceral mass samples (Figure 5). Both tissues contained the major analogs C1 and 2, GTX2 and 3, GTX5, dcGTX2 and 3, and dcSTX. We detected trace amounts of GTX4, Neo, and STX in some viscera samples, while STX and Neo were not detected in any of the siphon samples.

The variation in the molar concentration of each toxin and its contribution to total toxicity in the siphon and viscera during the monitoring period is shown in Figure 5. In the siphon, the molar content was $16 \mathrm{nmol} \mathrm{g}^{-1}$ in February and decreased to $1 \mathrm{nmol} \mathrm{g}^{-1}$ in June (Figure 5A). C1 and 2 were the prevalent toxins in all the samples throughout the monitoring period. These analogs represented $95 \%$ of the total PSTs content in the siphon samples during February and decreased to $28 \%$ at the end of the sampling period (Figure $5 \mathrm{C}$ ). The reduction of $\mathrm{C} 1$ and 2 was accompanied with an increase of GTX5, dcGTX2, and dcSTX to a maximum combined relative concentration of $60 \%$ $\left(0.6 \mathrm{nmol} \mathrm{g}^{-1}\right.$; Figure $\left.5 \mathrm{C}\right)$. The contribution to total toxicity in terms of STX equivalents of each analog is shown in Figure 5E. Type C toxins contributed up to $73 \%$ to the toxicity in January. With the reduction of $\mathrm{C} 1$ and 2 in the siphon, a significant increase of dcSTX contribution to total toxicity was detected at the end of the sampling period (68\% in June, Figure 5E).

Toxin content in the visceral mass was $457 \mathrm{nmol} \mathrm{g}^{-1}$ in January 2015 and decreased to $3.6 \mathrm{nmol} \mathrm{g}^{-1}$ in February 2016 (Figure 5B). Similar to the siphon samples, $\mathrm{C} 1$ and 2 were the dominant analogs (Figure 5D) in February 2015 since they represented $90 \%$ of the molar content $\left(384 \mathrm{nmol} \mathrm{g}^{-1}\right)$. In contrast with the siphon, there was a sharp reduction of the concentration of these toxins with time in viscera (Figure 5D). However, an increase of $\mathrm{C}$ toxins with respect to previous concentrations was detected two times in May. PSTs molar concentration of $\mathrm{C}$ toxins increased from $18 \%$ on April 24 to $33 \%$ on May 1 and from $22 \%$ on May 12 to $44 \%$ on May 19 (Figure 5D). The reduction of $\mathrm{C}$ toxins was accompanied with the appearance of GTX5 and the more potent toxins, dcSTX and dcGTX2 (Figure 5F). After February, dcSTX was the analog that contributed the most to total toxicity. The highest dcSTX concentration $\left(338 \mathrm{nmol} \mathrm{g}^{-1}\right)$ was detected on 

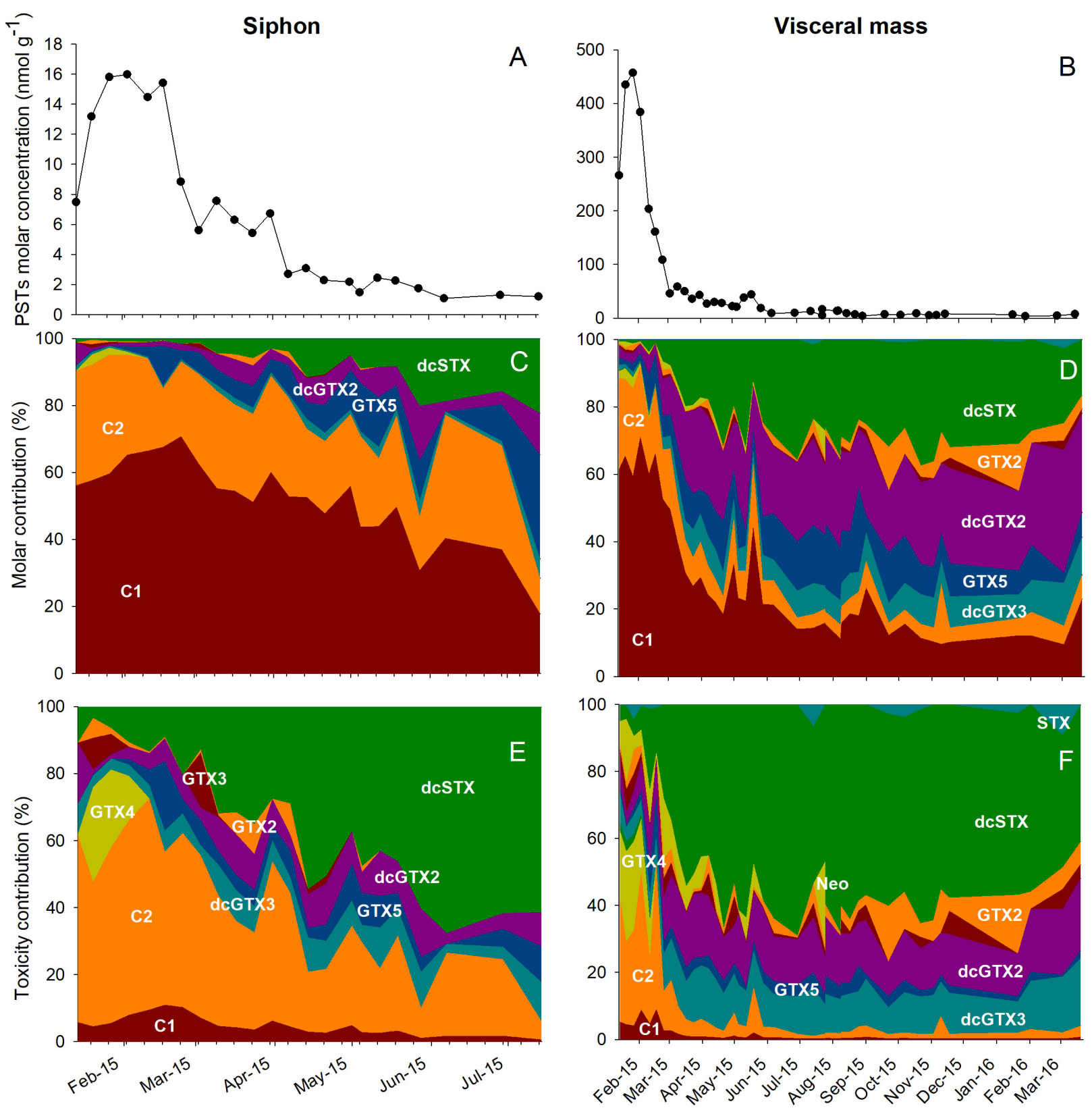

FIGURE 5 | Paralytic toxins in the siphon (A,C,E) and in the visceral mass (B,D,F) of geoduck samples collected from January 2015 to April of 2016 . The paralytic toxins molar concentration ( $\mathrm{nmol} \mathrm{g}^{-1}$ ) is presented in $\mathbf{A}$ and $\mathbf{B}$. The molar contribution (in \%, C,D) and toxicity contribution (in \%, E,F) of different paralytic toxins analogs detected during the sampling period is also shown. The toxicity of each analog was calculated according to the toxin equivalent factors shown in Table $\mathbf{1}$.

May 12 and represented $63 \%$ of the $2,610 \mu \mathrm{g}$ STX eq kg-1 calculated on this date. At the end of the monitoring period, low STX concentrations were detected (maximum concentration of $1.2 \mathrm{nmol} \mathrm{g}^{-1}$ ) that represented the $9 \%$ of the toxicity calculated in March 2016 (50 $\mu \mathrm{g}$ STX eq kg ${ }^{-1}$ ).

There is a limitation on the detection and quantification of PSTs analogs by HPLC-PCOX. The detection of PSTs by this method was only directed to the commercially toxin certified reference materials available when the method was developed. Therefore, to evaluate the presence of other analogs, 10 selected viscera samples were also analyzed by HILIC-MS/MS. This methodology allowed the detection of 12 other analogs not detected by HPLC-PCOX, including type $M$ toxins. The five $M$ analogs described so far were all detected in the tissue samples. M5 was the most abundant M-toxin, followed by M1 and M3. M-toxins represented between 30\% (230 nmol g-1, January 20) and $75 \%$ (28 $\mathrm{nmol} \mathrm{g}^{-1}$, June 29) of total PSTs detected by HILICMS/MS (Table 2). There was not a clear pattern in time of the contribution of M-toxins to total PSTs. Considering the TEFs shown in Table 1, the concentration of these toxins represented 
TABLE 2 | Contribution of M-toxins to molar concentration $\left(\mathrm{nmol} \mathrm{g}^{-1}\right)$ of PST and

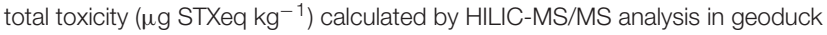
visceral mass samples.

\begin{tabular}{|c|c|c|c|c|}
\hline \multirow[t]{2}{*}{ Sample date } & \multicolumn{2}{|c|}{$\mathrm{nmol} \mathrm{g} \mathbf{g}^{-1}$} & \multicolumn{2}{|c|}{ Toxicity ( $\mu \mathrm{g} \mathrm{STXeq} \mathbf{k g}^{-1}$ ) } \\
\hline & Total & M-toxins & Total & M-toxins \\
\hline $1 / 14 / 2015$ & 497.7 & $131.6(52.9 \%)$ & $1,8633.7$ & $10,970.8$ (58.9\%) \\
\hline $1 / 20 / 2015$ & 768.9 & 118 (30.7\%) & $29,448.9$ & 9, $842.4(33.4 \%)$ \\
\hline $1 / 27 / 2015$ & $1,086.9$ & $241.4(44.4 \%)$ & 41,027 & $20,119(49 \%)$ \\
\hline $1 / 17 / 2015$ & 154.6 & $34.6(44.8 \%)$ & $6,026.6$ & $2,884.1(47.9 \%)$ \\
\hline 3/17/2015 & 58.1 & 15.3 (52.8\%) & 3236.5 & 1, $279.6(39.5 \%)$ \\
\hline $5 / 1 / 2015$ & 45.9 & $13.2(57.7 \%)$ & 3844.7 & 1, $103.6(28.7 \%)$ \\
\hline $6 / 29 / 2015$ & 37.8 & $14.1(74.8 \%)$ & 2450.2 & 1, $179(48.1 \%)$ \\
\hline $8 / 17 / 2015$ & 51.6 & $13.3(52.1 \%)$ & 2813.1 & 1, $109.6(39.4 \%)$ \\
\hline 8/25/2015 & 11.2 & $3.3(58.5 \%)$ & 885.9 & 274.7 (31\%) \\
\hline $11 / 10 / 2015$ & 12.0 & $2.8(45.9 \%)$ & 1023.7 & 230.5 (22.5\%) \\
\hline
\end{tabular}

9,718 $\mu \mathrm{g}$ STXeq $\mathrm{kg}^{-1}$ on January 20 (33\% of total toxicity) and $1,838 \mu \mathrm{g} \mathrm{STXeq} \mathrm{kg}^{-1}$ on June 29 (48\% of total toxicity, Table 2 ).

\section{DISCUSSION}

Here, we report PSTs profiles in the viscera and the siphon tissues of P. globosa. This is the first characterization of the transformation and depuration of different analogs in a geoduck clam. The accumulation of PSTs in P. globosa was associated with a HAB of $G$. catenatum that was present in the NGC during the first months of 2015. HABs of G. catenatum have been reported in different areas of the GC (Band-Schmidt et al., 2010), but they have not been registered in the NGC since there was not a continuous monitoring program in the region. Monitoring of PSTs in organisms extracted from areas located south from San Felipe initiated in 2010 and the first sanitary ban for the extraction of $P$. globosa was implemented in the same year. As a consequence, FICOTOX research laboratory has been monitoring the phytoplankton community in the area since 2011. We have documented that G. catenatum is a conspicuous species of the phytoplankton community from December to April with abundances lower than $10 \times 10^{3}$ cells $\mathrm{L}^{-1}$ (Murillo-Marínez, 2011). However, in 2015, the abundance reached $152 \times 10^{3}$ cells $\mathrm{L}^{-1}$ in samples collected at the surface of the water column. The presence of G. catenatum was related to maximum toxicity of $16,740 \mu \mathrm{g}$ STXeq $\mathrm{kg}^{-1}$ (27 the RL) in viscera of $P$. globosa. In 2017, another bloom was registered in the region and maximum registered abundance of the dinoflagellate $\left(283 \times 10^{3}\right.$ cells $\mathrm{L}^{-1}$ in surface water samples) and associated accumulation of PSTs $\left(49,166 \mu \mathrm{g}\right.$ STX eq $\mathrm{kg}^{-1}$ in viscera samples) in $P$. globosa increased importantly.

Although the relationship between the two variables is complex, the abundance of G. catenatum seems not particularly high when considering the PSTs concentrations and total sample toxicity quantified in the clams. Higher abundances of this species have been reported during HABs in other regions. In the GC, for example, G. catenatum blooms have been associated with wild and cultured animals die-offs, economical loses
(Núñez-Vázquez et al., 2011) and caused human intoxications and fatalities (Morey-Gaines, 1982; De la Garza, 1983; Mee et al., 1985; Band-Schmidt et al., 2010). Abundances registered during these HABs were in the order of $1 \times 10^{6}$ cells L $^{-1}$ (Morey-Gaines, 1982; De la Garza, 1983; Mee et al., 1985; Band-Schmidt et al., 2010). G. catenatum has also been reported in high abundances in others parts of the world. In Spain, abundances of $2 \times 10^{6}$ cells $\mathrm{L}^{-1}$ were reported in 1986 causing the accumulation of up to 26,400 $\mu \mathrm{g}$ STX eq $\mathrm{kg}^{-1}$ in mussels (Anderson et al., 1989). In Portugal, the dinoflagellate has occurred since 1986, with blooms in autumn of 1986, 1990, 1992, 1994, 1995, and annually from 2005 to 2012 (Vale et al., 2008; Silva et al., 2015) with abundances as high as $22 \times 10^{4}$ cells $\mathrm{L}^{-1}$ in 2007 (Rodrigues et al., 2012). Intermittent and multiannual scale blooms of G. catenatum are devastating to mussel aquaculture production in Galicia and to the harvesting of natural shellfish banks on the Galician and Portuguese coasts. Toxin levels of up to $60,000 \mu \mathrm{g}$ STX eq. $\mathrm{kg}^{-1}$ in mussel meat were reported in 2005 and 2010 (Pazos et al., 2006; Vale et al., 2008), leading to prolonged harvesting closures lasting until the following spring (Trainer et al., 2010). G. catenatum surface abundance did not reflect the magnitude of the HAB event in the NGC since this species can be distributed subsuperficially. The high relative abundances detected in net tow samples of the NGC in this study indicate this subsurface distribution.

The high levels of toxin accumulation and the time required for toxin depuration in the clams was related to the long duration of the HAB. The presence of G. catenatum, in January, part of February and from March to May caused that PSTs in viscera remained above the RL for almost all 2015. The characterization of PSTs concentration changes in terms of STX eq is essential for regulation purposes. The calculated depuration rate of $P$. globosa was $4.3 \%$ of STX eq loss per day. Therefore, after the accumulation of $16,740 \mu \mathrm{g}$ STX eq $\mathrm{kg}^{-1}$ in viscera, total PSTs should have reached the RL 106 days after this maximum level of toxicity. However, the RL was reached 104 days later than the date estimated by the exponential decay model. PSTs concentrations were found to decrease in time but there were periods when the toxicity increased compared to previous measurements (Figures 3C,D). This increase in toxicity was related to the increase in the abundance of $G$. catenatum in the water column that represented a continuous source of PSTs for geoduck clams. This consequently represents a bias in the calculation of the depuration rate in P. globosa. However, even with an under-estimation of the rate, it is evident that this species is a low depuration organism since it accumulates toxins for several months in their visceral tissues. Bricelj and Shumway (1998) classified bivalves that need several months to years to detoxify below the RL and present detoxification rates between 0.1 and $4 \%$ of STX eq loss per day, as a low depuration species. In contrast, a fast depurator bivalve has an elimination rate between 6 and 17\% of toxin loss per day, and reach the RL between 1 and 10 weeks, depending on the amount of toxin assimilated (Bricelj and Shumway, 1998). Panopea species have low depurating physiology since $P$. generosa was also found to retain toxicity for long periods of time (Curtis et al., 2000). Another low depuration clam species is Saxidomus giganteus with an average 
of $0.7 \%$ of STX eq loss per day in the whole tissues (Quayle, 1969; Madenwald, 1985; Price et al., 1991), Spisula solidissima depurates at $1.9 \%$, measured in whole animals (Shumway et al., 1988), Placopecten magellanicus at $0.6 \%$ when pools of digestive tissues, gills, and mantle are measured (Shumway et al., 1988), and Patinopecten yessoensis with an average of $2.6 \%$ in digestive tissues (Nishihama, 1980; Ogata et al., 1982; Tazawa et al., 1988).

$\mathrm{C} 1$ and $\mathrm{C} 2$ were the most abundant analogs in the siphon and viscera samples collected close to the HAB occurrence. These are the main analogs present in G. catenatum and represented 95\% of the PSTs detected in phytoplankton samples during the bloom, dcGTX3, dcNeo, and GTX2 and 3 comprised the remaining 5\%, (Bustillos-Guzmán et al., 2016; García-Mendoza et al., in preparation). Following the incorporation of toxins into the clam tissues through feeding activities, toxins transformation occurred principally in the viscera, where the low potency toxins $\mathrm{C} 1$ and 2 were converted into GTX5 and the more toxic analogs dcGTX2 and dcSTX. The presence of high toxic analogs and the increase in its relative contribution to the PSTs content in viscera caused that the toxicities remained above the RL for several months. Since there is a high number of analogs and different reactions involved in their transformation (Cembella et al., 1994; Oshima, 1995; Guéguen et al., 2011; Turner et al., 2012b, 2013), it is difficult to describe all the biotransformation steps and conversion rates that occurred in P. globosa after toxin bioaccumulation. However, we identified the principal biotransformation reactions in this species (Figure 6). Epimerization occurred between the epimeric pairs $\mathrm{C} 1$ and 2 and dcGTX2 and 3. C1 was then converted into GTX 5 by desulfuration in R3 position or into dcGTX2 by desulfocarboxylation in R4. C1 can also be transformed into dcSTX if both reactions occur in parallel. However, according to the time of appearance of PSTs analogs in P. globosa, it is more likely that formation of GTX5 is an intermediate step for the formation of dcSTX by desulfo-carboxylation in the R4 position. These biotransformation reactions explain the observation of the reduction of $\mathrm{C} 1$ and 2 which was accompanied with an increase in GTX5, dcGTX2, and dcSTX to a maximum combined relative concentration of 59\%. Even when enzymatic conversion of PSTs analogs to decarbamoyl (dc) derivatives is uncommon among bivalves (Bricelj and Shumway, 1998) and has been only demonstrated in the Pacific clam Protothaca staminea (Sullivan et al., 1983), the surf clam Spisula solida (Turner et al., 2013) and

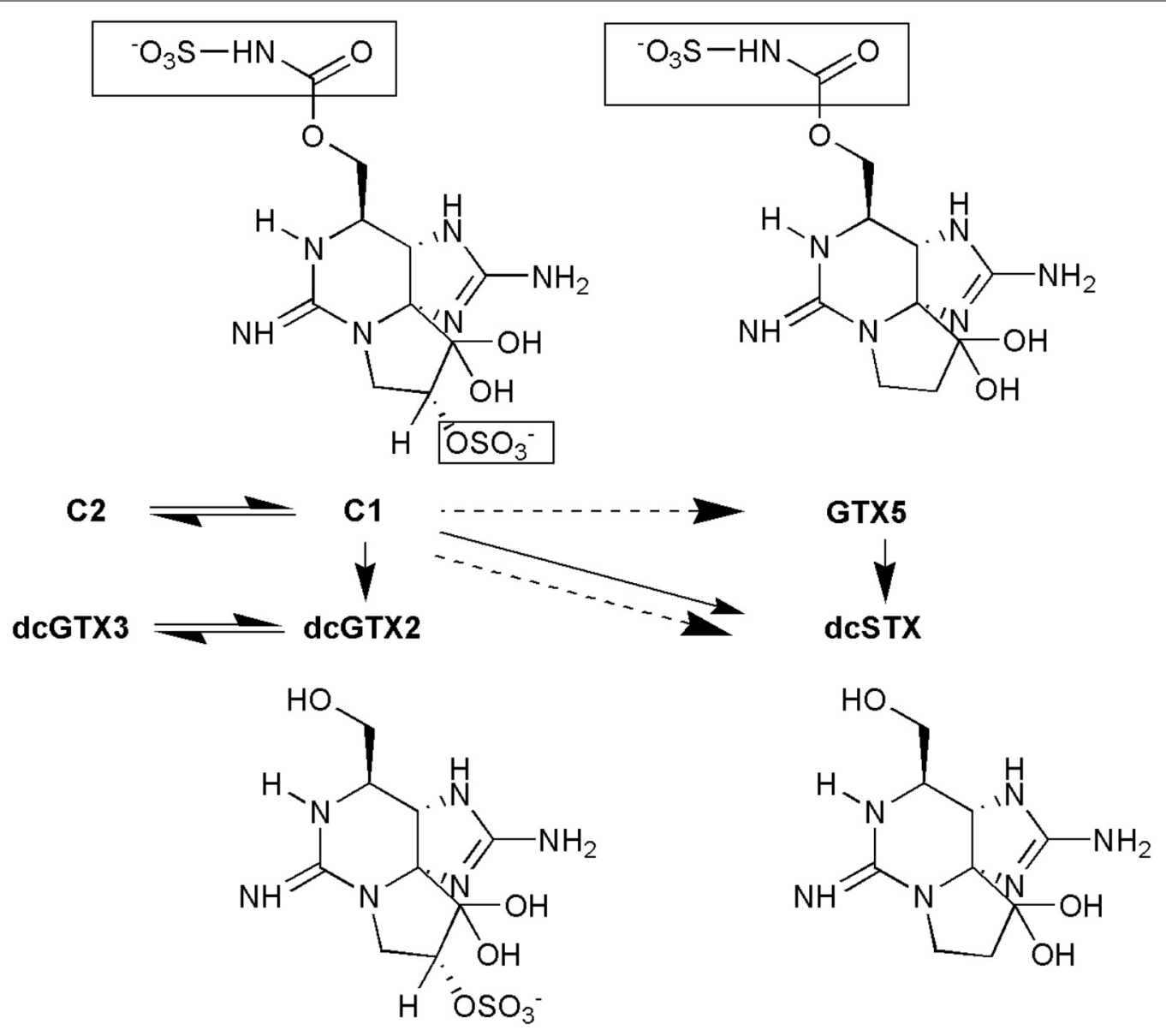

FIGURE 6 | Diagram of assumed biotransformations that occurred in viscera of geoduck Panopea globosa contaminated with Gymnodinium catenatum paralytic shellfish toxins. The part of the molecule that is modified to become in another analog is highlighted in a square. Solid arrow: desulfo-carboxylation, dashed arrow: desulfurization, double arrow: epimerization. 
in the Japanese clams Mactra chinensis and Peronida venulosa (Oshima, 1995), we identified in this study the production of dcGTX2 and 3 and dcSTX by N-sulfocarbamoyl toxins hydrolysis.

The characterization of the PSTs conversion steps and conversion rates becomes more complicated if the M-toxins are considered. Five $\mathrm{M}$ analogs were present in $P$. globosa tissues and represented a significant proportion (between 30$75 \%)$ of the PSTs detected in the samples. This is the first time that M-toxins are reported in geoduck clams. These analogs were described in 2008 in blue mussels (Mytilus edulis and Mytilus trossulus) from eastern Canada during a $\mathrm{HAB}$ of Alexandrium tamarense (Dell'Aversano et al., 2008). M-toxins are most probably metabolites or degradation products formed in shellfish since they have not been detected in microalgae (Dell'Aversano et al., 2008). Five M-toxins analogs have been described. Vale (2010) found that M1 is the most abundant in species that retain PSTs toxins for longer periods. M1 toxin has been reported in mussels (Mytilus galloprovinciallis), cockles (Cerastoderma edule), and clams from estuarine (Ruditapes decussatus) and oceanic habitats (Donax trunculus and Ensis spp.) collected in Portugal during a $\mathrm{HAB}$ of G. catenatum (Vale, 2010). M1 could contribute to an important fraction of the PSTs profile (up to 70\% of total GTX5) and has been proposed that it is originated from the metabolism of GTX5 (Vale, 2010). In the case of P. globosa, M5 was the most abundant M-toxin. Probably, there is a rapid transformation of some other M-toxins into M5 in this species. Metabolism and biotransformation of this type of toxins has not yet been elucidated.

The results of the present work have important implications for both regulation and management. Evaluation of the phytoplankton community in the NGC should be performed more intensively during winter to monitor the appearance of harmful species. The presence of G. catenatum should be evaluated not only in surface samples but also in water samples throughout appropriate depths within the water column, or vertical net hauls, tube integrated or hose integrated samples must be analyzed. Risk abundance indexes should also be developed to evaluate the possible accumulation of PSTs in geoduck clams above the RL.

Panopea globosa accumulated approximately 24 times more toxins in the viscera than in the siphon. Curtis et al. (2000) reported that accumulation of PSTs in viscera of $P$. generosa was 30 times higher than in the siphon. At the beginning of the fishery in the 1970s, PSTs were not considered by the Washington State Department of Health as a public health risk because the geoduck viscera were presumed to be discarded. However, it was later discovered that some members of a Native American tribe and of Asian immigrant communities in the United States consumed the viscera in soup (Curtis et al., 2000). Therefore, the sanitary programs of United States included the viscera as the target tissue for PSTs analyzes. This approach was adopted recently in Mexico to be in accordance with the United States regulation (Secretaría de Salud, 2016). The visceral ball is easily separated from the siphon and mantle without risk of contamination. Consequently, it is considered that consumption of the siphon is safe since muscle tissue does not accumulate high concentration of PSTs (Curtis et al., 2000). Geoduck Clam Biotoxin Monitoring Plan of Alaska (Alaska Department of Environmental Conservation, 2017) considers evisceration and use of the siphon in some cases when unacceptable levels of PSTs are detected in viscera. We found that the accumulation of toxins in muscular tissue was proportional to the concentration of PSTs in the viscera. This indicates that a fix proportion of the toxins present in the viscera are translocated to the muscle. The siphon will exceed the RL when visceral mass accumulates 18,424 $\mu \mathrm{g}$ STX eq $\mathrm{kg}^{-1}$. More data with high PSTs concentrations in the siphon are needed to describe a more robust statistical relation, but it is clear that this tissue can present toxicity above the RL, as actually occurred in the HAB of 2017. In this year, PSTs concentrations in viscera were almost three times higher than in 2015 and the PSTs concentration in the siphon exceeded the RL on three dates. These results have important regulatory implications since the siphon could present a concentration above the RL if there is a high accumulation of PSTs in viscera.

The mouse bioassay (MBA; Anon, 2005) was the only approved method for PSTs detection in shellfish for regulatory purposes. Recently, European Community, Canada (Turner et al., 2012a), and United States (U.S. Food and Drug Administration, 2015) sanitary legislations included HPLCbased methodologies as alternative methods to monitor these toxins. The presence of M-type toxins in shellfish represents a monitoring challenge since the MBA will be eliminated from sanitary monitoring programs. There are no certified reference standards of these toxins and its quantification and toxicity estimation have been performed based on structure-activity relations with other saxitoxin analogs (Dell'Aversano et al., 2008). In the case of P. globosa, we estimated that $M$ toxins represented up to $49 \%$ of calculated total toxicity in some samples. Furthermore, the contribution of M-toxins to total toxicity was not dependent on the depuration process in the clam. The relative concentration of these analogs did not vary with time after the clams were exposed to G. catenatum. Importantly, P. globosa represents a potential source of these toxins for isolation due to high concentrations found in viscera. The results obtained in the present work are important to elucidate biotransformation pathways in the metabolism of PSTs in an economically important bivalve. In addition, they are important to develop management plans for the $P$. globosa fishery since PST producing blooms have become recurrent (last documented bloom occurred in January 2018) in the last years in the NGC.

\section{AUTHOR CONTRIBUTIONS}

JM-E processed geoduck samples for PSTs determination, analyzed and interpreted the data, checked the data for accuracy and integrity, and wrote the manuscript. EG-M interpreted and reviewed the data for accuracy and integrity, wrote and edited the manuscript. AT performed HILIC-MS/MS analysis, revised and corrected the manuscript. YS-B and RM-M performed phytoplankton analysis and interpreted the associated data. 


\section{FUNDING}

This work was supported by CONACyT scholarship 242882 - CV 353239; FORDECYT - CONACyT project number 260040-2015; Red Temática sobre Florecimientos Algales Nocivos, CONACyT (RedFAN), 2015-2017 projects; and Cefas, Seedcorn internal funding (contract code DP345).

\section{REFERENCES}

Alaska Department of Environmental Conservation (2017). Geoduck Clam Biotoxin Monitoring Plan. Division of Environmental Health - Food Safety and Sanitation Program. Alaska: Alaska Department of Environmental Conservation, 7 .

Andersen, P., and Throndsen, J. (2004). "Estimating cell numbers," in Manual on Harmful Marine Microalgae, eds G. M. Hallegraeff, D. M. Anderson, and A. D. Cembella (Paris: UNESCO), 99-130.

Anderson, D. M., Sullivan, J. J., and Reguera, B. (1989). Paralytic shellfish poisoning in northwest Spain: the toxicity of the dinoflagellate Gymnodinuim catenatum. Toxicon 27, 665-674. doi: 10.1016/0041-0101(89)90017-2

Anon, S. (2005). “AOAC official method 959.08. Paralytic Shellfish Poison. Biological method. Final action," in AOAC Official Methods for Analysis, Chapter 49: Natural Toxins, 18th Edn, ed. M. W. Truckses (Gaithersburg, MD: AOAC International), 79-80.

Aragón-Noriega, E. A., Alcántara-Razo, E., Calderon-Aguilera, L. E., and SánchezFourcade, R. (2012). Status of geoduck clam fisheries in Mexico. J. Shellfish Res. 31, 733-738. doi: 10.2983/035.031.0317

Band-Schmidt, C. J., Bustillos-Guzmán, J. J., Gárate-Lizárraga, I., López-Cortés, D. J., Núñez-Vázquez, E. J., and Hernández-Sandoval, F. E. (2010). Ecological and physiological studies of Gymnodinium catenatum in the Mexican Pacific: a review. Mar. Drugs 8, 1935-1961. doi: 10.3390/md8061935

Botana, L. M. (2000). Seafood and Freshwater Toxins: Pharmacology, Physiology and Detection. New York, NY: CRC Press, 816.

Boundy, M. J., Selwood, A. I., Harwood, D. T., McNabb, P. S., and Turner, A. D. (2015). Development of a sensitive and selective liquid chromatography-mass spectrometry method for high throughput analysis of paralytic shellfish toxins using graphitised carbon solid phase extraction J. Chromatogr. A 1387, 1-12. doi: 10.1016/j.chroma.2015.01.086

Bricelj, V. M., Connell, L., Konoki, K., MacQuarrie, S. P., Scheuer, T., Catterall, W. A., et al. (2005). Na+ channel mutation leading to saxitoxin resistance in clams increases risk of PSP. Nature 434, 763-767. doi: 10.1038/nature03415

Bricelj, V. M., and Shumway, S. E. (1998). paralytic shellfish toxins in bivalve molluscs: occurrence, transfer kinetics, and biotransformation. Rev. Fish. Sci. 6, 315-383. doi: 10.1080/10641269891314294

Bureau, D., Rajas, W., Surry, N. W., Rand, C. M., Dovey, G., and Campbell, A. (2002). Age, size structure and growth parameters of geoducks (Panopea abrupta, Conrad 1849) from 34 locations in British Columbia sampled between 1993 and 2000. Can. Tech. Rep. Fish. Aquat. Sci. 2413:84.

Bustillos-Guzmán, J. J., Leyva-Valencia, I., Hernández-Sandoval, F. E., BandSchmidt, C. J., López-Cortés, D. J., and Núñez-Vázquez, E. J. (2016). "Ficotoxinas en aguas del Golfo de California: una revisión," in Florecimientos Algales Nocivos en México, eds E. García-Mendoza, S. I. Quijano-Scheggia, A. Olivos-Ortíz, and E. J. Núñez-Vazquez (Ensenada: CICESE), 162-179.

Cembella, A. D., Shumway, S. E., and Larocque, R. (1994). Sequestering and putative biotransformation of paralytic shellfish toxins by the sea scallop Placopecten magellanicus: seasonal and spatial scales in natural populations. J. Exp. Mar. Biol. Ecol. 180, 1-22. doi: 10.1016/0022-0981(94)90075-2

Cestèle, S., and Catterall, W. A. (2000). Molecular mechanisms of neurotoxin action on voltage-gated sodium channels. Biochimie 82, 883-892. doi: 10.1016/ S0300-9084(00)01174-3

Comisión Federal para la Protección contra Riesgos Sanitarios (2015). Presencia de marea roja en México durante 2015. Secretaría de Salud. Available at: http: //www.cofepris.gob.mx/ [accessed November 25, 2016].

Cudney-Bueno, R., Lavín, M. F., Marinone, S. G., Raimondi, P. T., and Shaw, W. (2009). Rapid effects of marine reserves via larval dispersal. PLoS One 4:e4140. doi: 10.1371 /journal.pone. 0004140

\section{ACKNOWLEDGMENTS}

We thank Atenea en el Mar company for providing geoduck and water samples and Dr. Juan Blanco for the guide and invaluable comments that helped to improve the work. We also thank Dr. Marcela Ovalle Marroquin and Dr. David Rivas for the review of the final draft of the manuscript.

Curtis, K. M., Trainer, V. L., and Shumway, S. E. (2000). Paralytic shellfish toxins in geoduck clams (Panopea abupta): variability, anatomical distribution and comparison of two toxin detection methods. J. Shellfish Res. 19, 313-319. doi: 10.1080/10641269891314294

De la Garza, A. J. (1983). Intoxicación alimentaria por ingestión de mariscos contaminados. Sal. Pub. Mex. 25, 145-150. doi: 10.3305/nh.2015.32.2.9205

Dell'Aversano, C., Walter, J. A., Burton, I. W., Stirling, D. J., Fattorusso, E., and Quilliam, M. A. (2008). Isolation and structure elucidation of new and unusual saxitoxin analogues from mussels. J. Nat. Prod. 71, 1518-1523. doi: 10.1021/ np800066r

Espinosa-Carreón, T. L., and Valdéz-Olguín, J. E. (2007). Variabilidad interanual de clorofila en el Golfo de California. Ecol. Apl. 6, 83-92.

Gárate-Lizárraga, I., Bustillos-Guzmán, J. J., Alonso-Rodríguez, R., and Luckas, B. (2004). Comparative paralytic shellfish toxin profiles in two marine bivalves during outbreaks of Gymnodinium catenatum (Dinophyceae) in the Gulf of California. Mar. Poll. Bull. 48, 378-402. doi: 10.1016/j.marpolbul.2003. 10.032

Gárate-Lizárraga, I., Bustillos-Guzmán, J. J., López-Cortés, D. J., HernándezSandoval, F., Erler, K., and Luckas, B. (2006). Paralytic shellfish toxin profiles in net phytoplankton samples from Bahía Concepción, Gulf of California, Mexico. Mar. Poll. Bull. 52, 800-815. doi: 10.1016/j.marpolbul.2006.03.003

Goodwin, C. L., and Pease, B. C. (1987). The distribution of geoduck (Panopea abrupta) size, density and quality in relation to habitat characteristics such as geographic area, water depth, sediment type and associated flora and fauna in Puget Sound, Washington. Technical Report no. 102. Olympia, WA: Washington Department of Fisheries.

Guéguen, M., Baron, R., Bardouil, M., Truquet, P., Haberkorn, H., Lassus, P., et al. (2011). Modelling of paralytic shellfish toxin biotransformations in the course of Crassostrea gigas detoxification kinetics. Ecol. Model. 222, 3394-3402. doi: 10.1016/j.ecolmodel.2011.07.007

Gutiérrez, O. Q., Marinone, S. G., and Parés-Sierra, A. (2004). Lagrangian surface circulation in the Gulf of California from a 3D numerical model. Deep Sea Res. 51, 659-672. doi: 10.1016/j.dsr2.2004.05.016

Harwood, D. T., Selwood, A. I., Van Ginkel, R., Waugh, C., McNabb, P. S., Munday, R., et al. (2014). Paralytic shellfish toxins, including deoxydecarbamoyl-STX, in wild-caught Tasmanian abalone (Haliotis rubra). Toxicon 90, 213-225. doi: 10.1016/j.toxicon.2014.08.058

Jaime, E., Gerdts, G., and Luckas, B. (2007). In vitro transformation of PSP toxins by different shellfish tissues. Harmful Algae 6, 308-316. doi: 10.1016/j.hal.2006. 04.003

Lewitus, A. J., Horner, R. A., Caron, D. A., García-Mendoza, E., Hickey, B. M., Hunter, M., et al. (2012). Harmful algal blooms along the North American west coast region: history, trends, causes, and impacts. Harmful Algae 19, 133-159. doi: 10.1016/j.hal.2012.06.009

Madenwald, N. D. (1985). "Effect of water temperature on the loss of paralytic shellfish poison from the butter clam Saxidomus giganteus," in Toxic Dinoflagellates, eds D. M. Anderson, A. W. White, and D. G. Baden (New York: Elsevier-North Holland), 479-484.

Manrique, F. A., and Molina, R. E. (1997). Presencia de mareas rojas en la Bahía de Bacochibampo, Guaymas, Sonora, México. Hidrobiológica 7, 81-86.

Mee, L. D., Espinosa, M., and Díaz, G. (1986). Paralytic shellfish poisoning with a Gymnodinium catenatum red tide on the Pacific coast of Mexico. Mar. Environ. Res. 19, 77-92.

Mee, L. D., Ramírez-Flores, A., Flores-Verdugo, F., and González-Frías, F. (1985). Coastal upwelling and fertility of the Southern Gulf of California: impact of the 1982-83 ENSO event. Trop. Ocean Atmos. Newsl. 31, 9-10.

Morey-Gaines, G. (1982). Gymnodinium catenatum Graham (Dinophyceae): morphology and affinities with armoured forms. Phycologia 21, 154-163. 
Murillo-Marínez, R. (2011). Caracterización de Fitoplancton Tóxico y Acumulación de Toxinas de tipo Paralizante en la Almeja Panopea globosa (Dall 1898) en la Franja Costera de San Felipe-Puertecitos, B. C. Bachelor's degree thesis, Facultad de Ciencias de la Universidad Autónoma de Baja California, Ensenada.

Nishihama, Y. (1980). Seasonal abundance of Protogonyaulax sp. causing paralytic shellfish poisoning in Funka Bay, Hokkaido, Japan, 1978-1980. Anchorage: Proc. North Pacific Aquaculture Symp, 319-372.

Núñez-Vázquez, E. J., Gárate Lizárraga, I., Band-Schmidt, C. J., Cordero-Tapia, A., Hernández -Sandoval, F. E., and Heredia-Tapia, A. (2011). Impact of harmful algal blooms on wild and cultured animals in the Gulf of California. J. Environ. Biol. 32, 413-423.

Ogata, T., Kodama, M., Fukuyo, Y., Inoue, T., Kamiya, H., Matsuura, F., et al. (1982). The occurrence of Protogonyaulax spp. in Ofunato Bay, in association with the toxification of the scallop Patinopecten yessoensis. Bull. Jpn. Soc. Sci. Fish. 48, 563-566.

Oshima, Y. (1995). "Chemical and enzymatic transformation of paralytic shellfish toxins in marine organisms," in Harmful Marine Algal Blooms, eds P. Lassus, G. Arzul, E. Erard-Le Denn, P. Gentien, and C. Marcaillou-Le Baut (Paris: Lavoisier Publishing ILP), 475-480.

Pazos, Y., Moroño, A., Triñanes, J., Doval, M., Montero, P., Vilarinho, M. G., et al. (2006). "Early detection and intensive monitoring during an unusual toxic bloom of Gymnodinium catenatum advected into the Galician Rías (NW Spain," in Proceedings of the 12th International Conference on Harmful Algae, Copenhagen,

Price, D. W., Kizer, K. W., and Hansgen, K. H. (1991). California’s paralytic shellfish poisoning prevention program, 1927-89. J. Shellfish Res. 10, 119-145.

Quayle, D. (1969). Paralytic shellfish poisoning in British Columbia. Nanaimo: Fisheries Research Board of Canada Biological Station, 68.

Ramírez-Camarena, C., Martínez-García, A., Juárez-Ruíz, N., RojasCrisóstomo, R., and Rámírez-García, H. (2004). "Impactos de Pyrodinium bahamense var. compressum durante el florecimiento algal nocivo 2001-2002, en la Costa Suroeste de México," in Proceedings of the VI International Meeting of Planktology: XIII Reunión Nacional SOMPAC, (Nayarit: ITMar Núm), 62.

Rodrigues, S. M., De Carvalho, M., Mestre, T., Ferreira, J. J., Coelho, M., Peralta, R., et al. (2012). Paralytic shellish poisoning due to ingestion of Gymnodinium catenatum contaminated cockles - Application of the AOAC HPLC official method. Toxicon 59, 558-566. doi: 10.1016/j.toxicon.2012.01.004

Saldate-Castañeda, O., Vázquez-Castellanos, J. L., Galván, J., SánchesAnguiano, A., and Nazar, A. (1991). Poisoning from paralytic shellfish toxins in Oaxaca. México Sal. Pub. Mex. 33, 240-247.

Santiago-Morales, S. I. (2016). "Florecimientos algales nocivos en la costa de Oaxaca," in Florecimientos Algales Nocivos en México, eds E. García-Mendoza, S. I. Quijano-Scheggia, A. Olivos-Ortíz, and E. J. Núñez-Vazquez (Ensenada: CICESE), 242-255.

Secretaría de Pesca de Baja California (2016). Carta Estatal Pesquera de Baja California 2000-2015. Secretaría de pesca. Available at: http://www.sepescabc. gob.mx/x/salaDePrensa/difusionAcciones/docs/CartaEstatalPesquera.pdf [accessed January 15, 2018].

Secretaría de Salud. (2016). Guía para el laboratorio de análisis de agua de mar y moluscos bivalvos. Programa Mexicano de Sanidad de Moluscos Bivalvos. México: Secretaría de Salud, 94.

Shumway, S. E., Sherman-Caswell, S., and Hurst, J. W. Jr. (1988). Paralytic shellfish poisoning in Maine: monitoring a monster. J. Shellfish Res. 7, 643-652.

Silva, T., Caeiro, M. F., Reis Costa, P., and Amorim, A. (2015). Gymnodinium catenatum Graham isolated from the Portuguese coast: toxin content and genetic characterization. Harmful Algae 48, 94-104. doi: 10.1016/j.hal.2015. 07.008
Sournia, A. (1978). Phytoplankton Manual, Vol. 6. Paris: UNESCO Press, 1-337. Sullivan, J. J., Iwaoka, W, T., and Liston J. (1983). Enzymatic transformation of PSP toxins in the littleneck clam (Protothacastaminea). Biochem. Biophys. Res. Commun. 114, 465-472. doi: 10.1016/0006-291X(83)90803-3

Tazawa, T., Ito, T., Ishige, M., and Satoh, N. (1988). Seasonal variations of paralytic shellfish poison in scallops from Funka Bay. Rep. Hokkaido Inst. Public Health 38, 63-65.

Trainer, V. L., Pitcher, G. C., Reguera, B., and Smayda, T. J. (2010). The distribution and impacts of harmful algal bloom species in eastern boundary upwelling systems. Prog. Oceanogr. 85, 33-52. doi: 10.1016/j.pocean.2010.02.003

Turner, A. D., Dhanji-Rapkova, M., Algoet, M., Suarez-Isla, B. A., Cordova, M., Caceres, C., et al. (2012a). Investigations into matrix components affecting the performance of the official bioassay reference method for quantitation of paralytic shellfish poisoning toxins in oysters. Toxicon 59, 215-230. doi: 10. 1016/j.toxicon.2011.11.013

Turner, A. D., Lewis, A. M., Hatfield, R. G., Galloway, A. W., and Higman, W. A. (2012b). Transformation of paralytic shellfish poisoning toxins in Crassostrea gigas and Pecten maximus reference materials. Toxicon 60, 1117-1134. doi: 10.1016/j.toxicon.2012.07.013

Turner, A. D., Lewis, A. M., O'Neill, A., and Hatfield, R. G. (2013). Transformation of paralytic shellfish poisoning toxins in UK surf clams (Spisula solida) for targeted production of reference materials. Toxicon 65, 41-58. doi: 10.1016/j. toxicon.2013.01.008

Turner, A. D., McNabb, P. S., Harwood, D. T., Selwood, A. I., and Boundy, M. J. (2015). Single-laboratory validation of a multitoxin ultra-performance LC-hydrophilic interaction LC-MS/MS method for quantitation of paralytic shellfish toxins in bivalve shellfish. J. AOAC Int. 98, 609-621. doi: 10.5740/ jaoacint.14-275

U.S. Food and Drug Administration (2015). National Shellish Sanitation Program (NSSP), Guide for the Control of Molluscan Shellfish: 2015 Revision. Washington, DC: Government Printing Office, 445.

Vale, P. (2010). Metabolites of saxitoxin analogues in bivalves contaminated by Gymnodinium catenatum. Toxicon 55, 162-165. doi: 10.1016/j.toxicon.2009. 07.010

Vale, P., Botelho, M. J., Rodrigues, S. M., Gomes, S. S., and Sampayo, M. A. M. (2008). Two decades of marine biotoxin monitoring in bivalves from Portugal (1986-2006): a review of exposure assessment. Harmful Algae 7, 11-25. doi: 10.1016/j.hal.2007.05.002

Van de Riet, J., Gibbs, R. S., Mugg ah, P. M., Rourke, W. A., MacNeil, J. D., and Quilliam, M. A. (2011). Liquid chromatography post-column oxidation (PCOX) method for the determination of paralytic shellfish toxins in mussels, clams, oysters, and scallops: collaborative study. J. AOAC Int. 94, 1154-1176.

Wiese, M., D’Agostino, P. M., Mihali, T. K., Moffitt, M. C., and Neilan, B. A. (2010). Neurotoxic alkaloids: saxitoxin and its analogs. Mar. Drugs 8, 2186-2211. doi: $10.3390 / \mathrm{md} 8072185$

Conflict of Interest Statement: The authors declare that the research was conducted in the absence of any commercial or financial relationships that could be construed as a potential conflict of interest.

Copyright (๑) 2018 Medina-Elizalde, García-Mendoza, Turner, Sánchez-Bravo and Murillo-Martinez. This is an open-access article distributed under the terms of the Creative Commons Attribution License (CC BY). The use, distribution or reproduction in other forums is permitted, provided the original author(s) and the copyright owner(s) are credited and that the original publication in this journal is cited, in accordance with accepted academic practice. No use, distribution or reproduction is permitted which does not comply with these terms. 